\title{
Accuracy of Pedicle Screw Placement in Thoracolumbar Spine with Conventional Open Technique
}

\author{
Torakolomber Omurgaya Geleneksel Açık Teknik ile Pedikül Vidası \\ Uygulamasının Güvenilirliği
}

\author{
Alp Ozgun BORCEK, Halil Ibrahim SUNER, Hakan EMMEZ, Memduh KAYMAZ, Sukru AYKOL, \\ Aydın PASAOGLU \\ Gazi University, School of Medicine, Department of Neurosurgery, Ankara, Turkey
}

Corresponding Author: Alp Ozgun BORCEK / E-mail: alpborcek@gmail.com

\begin{abstract}
AIM: To demonstrate the incidence of screw misplacement and revision rates in a group of 72 patients that underwent pedicle screw fixation for spinal pathologies using the conventional, fluoroscopy-guided open technique.

MATERIAL and METHODS: Data from 72 consecutive patients with spinal instability that received 472 screws between April 2011 and May 2013 were reviewed and pedicle wall breach was graded as mild $(<3 \mathrm{~mm})$, moderate $(3-6 \mathrm{~mm})$ and severe $(>6 \mathrm{~mm})$. Direction of misplacement was also assessed in reformatted images as medial, lateral, superior and inferior (or in combinations).

RESULTS: The indications for pedicle screw placement were as follows: degenerative (59.7\%), trauma (13\%) and tumor (9.7\%). Pedicle screws were inserted between T9 and S1. In this series of the 472 screws, $29(6.1 \%)$ screws were implanted with minimal pedicle wall violation ( $\leq 3 \mathrm{~mm})$ and 16 screws $(3.4 \%)$ were implanted with moderate $(3-6 \mathrm{~mm})$ violations. There were no severe violations (more than $6 \mathrm{~mm})$ in this series. Pedicle violations were significantly higher in thoracic pedicles and in trauma patients when compared to other groups. Only two patients required pedicle screw repositioning after their index surgery.
\end{abstract}

CONCLUSION: Conventional open technique in pedicle screw placement is a safe and sound method with its low and acceptable complication rates

KEYWORDS: Open pedicle screw positioning, Pedicle breach, Pedicle screw, Pedicle screw malposition, Spinal instability, Thoracolumbar instability

öz

AMAÇ: Spinal patolojiler nedeni ile geleneksel, floroskopi kılavuzluğunda açık teknikle yöntemlerle pedikül vida uygulaması yapılan 72 hastadaki yanlış yerleşim ve revizyon oranlarının tespit etmek.

YÖNTEM ve GEREÇLER: Nisan 2011 ile Mayıs 2013 tarihleri arasında toplam 472 pedikül vidası kullanılarak ameliyat edilen 72 hastanın sonuçları retrospektif olarak incelendi ve malpozisyonlar hafif $(\leq 3 \mathrm{~mm})$, orta $(3-6 \mathrm{~mm})$ ve ciddi $(>6 \mathrm{~mm})$ olarak sınıflandırıldı. Ek olarak malpozisyonun yönü de medial, lateral, süperior ve inferior olarak incelendi.

BULGULAR: Hastaların \%59,7 sinde dejeneratif patoloji, \%13'ünde travma ve \%9,7sinde tümöral patoloji bulunmaktaydı. Pedikül vidaları bu hasta grubunda T9 ile S1 arasına yerleştirilmiştir. 472 vidanın $29(\% 6,1)$ tanesinde hafif; $16(\% 3,4)$ tanesinde de orta dereceli malpozisyon olduğu tespit edildi. Bu seride ciddi malpozisyonlu hasta bulunmamakta idi ( $6 \mathrm{~mm}$ 'den fazla). Yanlış yerleşimlerin büyük çoğunluğu istatistiksel olarak anlamlı şekilde torasik vertebrada ve travma hastalarında idi. Sadece 2 hastaya cerrahi sonrası malpozisyon nedeni ile ikinci bir revizyon cerrahisi uygulandı.

SONUÇ: Geleneksel açık pedikül vidalama tekniği düşük ve kabul edilebilir komplikasyon oranları ile güvenli ve etkili bir cerrahi tekniktir.

ANAHTAR SÖZCÜKLER: Açık pedikül vida yerleştirilmesi, Pedikül sıyırması, Pedikül vidası, Pedikül vidası malpozisyonu, Spinal instabilite, Torakolomber instabilite

\section{INTRODUCTION}

Spinal instrumentation is one of the most common procedures performed by both orthopedic surgeons and neurosurgeons for spinal instability resulting from traumatic, degenerative, malformative or tumoral pathologies. Pedicle screws have become more popular and an exponential increase in their usage is observed $(4,8,26)$, leading to questions regarding their safety and reliability. Successful application of pedicle screw insertion depends on experience, the technique used and indications. There is a wide variety of reports and no consensus on how to decide a screw is correctly positioned, requiring additional studies to clarify these issues. 
This study aims to investigate the safety and accuracy of open pedicle screw insertion technique for various indications.

\section{MATERIAL and METHODS}

Between April 2011 and May 2013, 72 patients underwent posterior spinal instrumentation with the conventional, free hand, open technique for their spinal pathologies at the Gazi University School of Medicine, Department of Neurosurgery. Patient charts, operation logs and postoperative computerized tomography (CT) scans were reviewed retrospectively. All patients presented with intractable pain and/or neurological deficits. Surgeries were performed by the same surgeons ( $\mathrm{AOB}$ and $\mathrm{HE}$ ). A standard, posterior midline approach was utilized. After performing neural decompression with laminectomies, facetectomies, corpectomies and discectomies via the posterior approach, pedicle screws were placed in a standard fashion using anatomical landmarks and intraoperative fluoroscopy guidance. The diameter and length of the screws were decided based on preoperative CT measurements for each level. Titanium, polyaxial screws of 4.0 to $7.5 \mathrm{~mm}$ in diameter and 35 to $55 \mathrm{~mm}$ in length were used as appropriate. Each patient underwent postoperative CT before mobilization in order to document screw position. All of the patients were examined with a 16-slice multidetector CT (Brightspeed, $\mathrm{GE}$, Milwaukee, WI) in the supine position without contrast material. Scan protocol was as follows: tube voltage, $130 \mathrm{kV}$; effective tube current-time product, $175 \mathrm{mAs}$; rotation time, 0.6 seconds; thickness, $1.25 \mathrm{~mm}$; table speed $27.5 \mathrm{~mm} /$ rot; pitch 1.375:1. Overlapping 2-mm-thick images (with 1-mm recon increment) were reconstructed from the raw dataset with a hard (bone) filter algorithm. Consecutive sagittal and coronal reformat images were obtained from this dataset.

Accuracy of screw position was judged according to the method described by Learch et al. (12), and modified to assess coronal and sagittal plane breach. Screw position was classified as normal, cortical encroachment or frank penetration. Normal screw was when the screw was in the pedicle completely with clearly visible pedicle walls. If the pedicle cortex could not be visualized and there was no obvious violation of the pedicle cortex, this was recorded as "cortical encroachment". And finally, if the screw was outside the pedicle boundaries, frank penetration was recorded. Frank penetration was further classified into minor $(<3 \mathrm{~mm})$, moderate $(3-6 \mathrm{~mm})$ and severe $(>6 \mathrm{~mm})$ according to Wiesner et al. (25). The number of screws, fused segments and level of vertebrae receiving screws were recorded.

\section{RESULTS}

The mean age of the patient population was $50.26 \pm 16.16$ years (range 14-76; median 52 years). There were 43 females (59.7\%) and 29 males (40.3\%). The most common indication for spinal instrumentation was degenerative spinal changes in $43(59.7 \%)$ patients. This was followed by trauma in 22 patients (30.6\%) and spinal tumors in 7 patients $(9.7 \%)$. A total of 472 screws were inserted during the study period. The median number of vertebra corpuses receiving pedicle screws was 3 (range: 2-6 corpuses). The median number of screws placed was 6 (range: 4-12 screws). The median number of segments fused was 2 (range: 1-7 segments). L4-L5 was the most frequently fused segment (43 patients; $59.7 \%$ ) followed by L3-L4 (41 patients; 56.9\%) and L2-L3 (27 patients; 37.5\%). Of the 472 screws, 264 (55.9\%) screws were inserted for degenerative spine, 170 (36.0\%) for trauma and 38 (8.1\%) for tumor.

Frank screw misplacement was observed in 45 (9.5\%) screws. Of these 45 screws, $29(6.1 \%)$ had minimal penetration (cortical perforation $\leq 3 \mathrm{~mm}$ ), and $16(3.4 \%)$ had moderate penetration (cortical penetration 3-6 mm). There was no severe penetration ( $>6 \mathrm{~mm}$ ) in this series. Additionally, none of the screw positions were judged as "cortical encroachment" and there were no complications such as pedicle fracture or anterior breach. T10 vertebra was the most frequent vertebra with misplaced screws in this series (4 of 14 screws; $28.5 \%$ ), followed by T11 and T12. Medial and lateral were the two most common misplacement directions. Medial pedicle wall breach was observed in 23 misplaced screws (51.1\%) while lateral pedicle wall misplacement was observed in 12 (26.6\%). The remaining misplaced pedicles were oriented in various directions. Table I demonstrates the distribution of misplaced screws with respect to the vertebra level, pathology treated and grade of displacement and Table II demonstrates the level of misplacement with respect to anatomical orientation of misplacement. The number of misplaced screws in the thoracic region (15 of 75 screws; 19.7\%) was significantly higher than in the lumbar region (27 of 368 screws; $7.3 \%$ ) $(p<0.001)$. Additionally, the number of misplaced screws for trauma (22 of 170 screws; 12.94\%) was significantly higher than that of degenerative disease (17 of 264 screws; $6.4 \%)(p<0.001)$. There was no difference between surgeons regarding the number of misplaced screws.

Two of 72 (3\%) patients underwent postoperative revision surgery for screw repositioning. The first patient who was complaining of postoperative severe radicular pain after surgery for degenerative spine had a $1.9 \mathrm{~mm}$ medial displacement at her right $\mathrm{S} 1 \mathrm{screw}$ and underwent immediate revision after demonstration of the misplacement. The other patient underwent a postoperative CT that demonstrated a $5.9 \mathrm{~mm}$ lateral displacement at her right L2 vertebra (the most severe displacement in the series) and a revision was performed to prevent fixation failure. None of the remaining 70 patients - including the ones with misplaced screws experienced any problems and were discharged uneventfully. The patients with pedicle wall breach were closely followed as regards future compromise.

\section{DISCUSSION}

There is still an ongoing debate about controversies surrounding pedicle screw usage. These concerns are mainly about the safety of the procedure. No matter how your technique is perfect and you use solely anatomical landmarks (22). The application of pedicle screws is ultimately a blind procedure even if you use sophisticated technical resources 
Table I: Number of Inserted and Failed Screws with Respect to Pathology Treated and Degree of Misplacement

\begin{tabular}{|c|c|c|c|c|c|c|c|c|}
\hline \multirow[b]{2}{*}{ Level } & \multicolumn{4}{|c|}{ Number of Screws Inserted } & \multicolumn{2}{|c|}{$\begin{array}{l}\text { Number of Frank } \\
\text { Penetrations }\end{array}$} & \multicolumn{2}{|c|}{$\begin{array}{c}\text { Percent of Misplaced } \\
\text { Screws }\end{array}$} \\
\hline & Tumor & Trauma & Degenerative & Total & Minimal & Moderate & $\mathbf{n}$ & $\%$ \\
\hline \multicolumn{9}{|c|}{ Thoracic Spine } \\
\hline T9 & 2 & 0 & 0 & 2 & 0 & 0 & 0 & .00 \\
\hline $\mathrm{T} 10$ & 4 & 10 & 0 & 14 & 0 & 4 & 4 & 28.57 \\
\hline $\mathrm{T} 11$ & 4 & 24 & 0 & 28 & 2 & 5 & 7 & 25.00 \\
\hline $\mathrm{T} 12$ & 6 & 26 & 0 & 32 & 1 & 3 & 4 & 12.50 \\
\hline Total & 16 & 60 & 0 & 76 & 3 & 12 & 15 & 19.7 \\
\hline \multicolumn{9}{|c|}{ Lumbar Spine } \\
\hline L1 & 2 & 22 & 4 & 28 & 1 & 1 & 2 & 7.14 \\
\hline L2 & 8 & 30 & 12 & 50 & 3 & 2 & 5 & 10.00 \\
\hline L3 & 6 & 30 & 58 & 94 & 6 & 1 & 7 & 7.45 \\
\hline L4 & 6 & 20 & 82 & 108 & 6 & 0 & 6 & 5.56 \\
\hline L5 & 0 & 8 & 80 & 88 & 7 & 0 & 7 & 7.95 \\
\hline Total & 22 & 110 & 236 & 368 & 23 & 4 & 27 & 7.3 \\
\hline \multicolumn{9}{|c|}{ Sacral Spine } \\
\hline S1 & 0 & 0 & 28 & 28 & 3 & 0 & 3 & 10.71 \\
\hline Total & 38 & 170 & 264 & 472 & 29 & 16 & 45 & 9.5 \\
\hline
\end{tabular}

Table II: Direction of Misplacement in Failed Screws

\begin{tabular}{|c|c|c|c|c|c|c|c|c|c|c|}
\hline & $\mathrm{T} 10$ & T11 & $\mathrm{T} 12$ & $\mathbf{L 1}$ & L2 & $\mathbf{L 3}$ & L4 & $\mathbf{L 5}$ & S1 & Total \\
\hline Inferior & - & - & - & - & - & - & - & - & 1 & 1 \\
\hline Inferolateral & 1 & 2 & - & - & - & - & - & - & - & 3 \\
\hline Inferomedial & - & - & - & - & - & - & 1 & 2 & 1 & 4 \\
\hline Lateral & 3 & 5 & 1 & 1 & 1 & 1 & - & - & - & 12 \\
\hline Medial & - & - & 3 & 1 & 4 & 6 & 4 & 4 & 1 & 23 \\
\hline Superior & - & - & - & - & - & - & 1 & 1 & - & 2 \\
\hline Total & 4 & 7 & 4 & 2 & 5 & 7 & 6 & 7 & 3 & 45 \\
\hline
\end{tabular}

such as navigation $(16,23)$ or even robots $(13)$ to assist the surgery. This increases the probability of complications such as dural, neural, vascular or visceral damage $(3,14,20)$. The definition of adequate pedicle screw position is also unclear. The radiological method (CT versus plain radiographs), cutoff points for measurements ( $2 \mathrm{~mm}$ versus $3 \mathrm{~mm}$ or others) of inadequate placements, or surgical techniques utilized (as in intentional in and out technique used in the thoracic spine) produce different results and cause a wide range of variability between studies regarding percentage of correct pedicle screw positioning (1). Additionally, most of the so-called "incorrect" placements do not correspond to the clinical results and the number of repositioning procedures with a second surgery and reported complications remains low. Studies in the literature demonstrate malposition rates as high as $42 \%$ for the conventional technique (1) and refinements using computer assistance are in progress showing promising results $(2,6,11,19,23)$.
Our study found a $9.5 \%$ overall rate of screw malposition and the malposition rate was significantly higher in the thoracic spine than in the lumbar spine. We tried to perform pedicular placement of the screws in all cases and did not use the "in and out" technique in our surgeries. Higher thoracic failure rates in our study are in accordance with the current literature. In their retrospective study including the whole thoracic spine (from T1 to T12) Belmont et al. reported the "fully contained" pedicle screw rate as 57\% (3). In another study, Guzey et al. reported a $20.3 \%$ rate for misplacement in their thoracic pedicle screw applications (5). Although there are more successful surgeons reporting a malposition rate as low as $0.4 \%$ (9), the generally reported high malposition rates result from the unique anatomy of the thorax. Pedicle diameters are small and pedicle angles relative to the vertebra corpus are narrower in this region. Anatomical studies on thoracic spine demonstrate that a different axial plane angle is required for 
almost every thoracic vertebra for successful pedicle screw insertion $(7,21)$. Additionally, the proximity of the spinal cord to the bony elements and the narrow nature of the thoracic spinal canal when compared to the other segments may complicate thoracic screw placement in this region (3, $10,18,24)$. Although there are different comments in the literature $(6,8)$, this problem may be handled by utilization of computer-assisted techniques $(2,11,15,19)$. Rajasekaran et al. performed a randomized clinical trial and found that pedicle breach rates were significantly higher using a conventional technique compared to a computer-assisted technique (23\% versus $2 \%$, respectively) in the thoracic spine (19). Similarly, in their meta-analysis comprising 7533 pedicle screws inserted with computer-assisted methods, Tian and $\mathrm{Xu}$ found $89.22 \%$ accuracy and concluded that computer assistance provides higher accuracy (23). In their randomized control clinical study comparing the computerassisted technique versus the conventional technique, Laine et al. demonstrated pedicle perforation rates of $4.6 \%$ and $13.4 \%$, respectively, and concluded that computer assistance provides more accurate screw placement (11). However, in their meta-analysis reporting overall placement accuracy of pedicle screws as $91.3 \%$ (in 37, 337 screws), Kosmopoulos and Schiaz (8) found that utilization of navigation did not help pedicle screw accuracy in the thoracic spine.

Most of the patients with misplaced screws do not experience severe side effects or require revision surgeries. In their study including 1084 thoracolumbar pedicle screws, Nottmeier et al. reported a $7.5 \%$ pedicle breach rate and only $0.2 \%$ per screw incidence of nerve root injury that did not lead to motor deficits (17). Our study had similar findings. The discrepancy between percentage of misplaced screws and percentage of neurological problems can be explained by the variability in the anatomical relationships between pedicles and neural structures. For example, Getzbein evaluated 71 lower thoracic pedicles and reported a rate of $26 \%$ for medial wall penetrations of up to $8 \mathrm{~mm}$ with only 2 minor neurological injuries and hypothesized a 4-mm safe zone between the medial pedicle wall and the spinal cord (4). Of course this information does not justify $8 \mathrm{~mm}$ medial wall penetration as safe but demonstrates the forgiving nature of anatomical relations between the spinal cord and pedicle walls. We believe, patients with misplaced screws should be followed up for future deterioration even when discharged uneventfully. These patients may experience various problems such as nerve injuries and construct failures.

The difference in the number of misplaced screws with respect to spinal pathology (trauma vs. degenerative) treated as demonstrated in our study requires further explanation. We found that the failure rates were higher for trauma cases when compared to degenerative spine cases. This can be explained by the high number of thoracic segments requiring pedicle screw insertion in the trauma cases when compared to the degenerative spine cases. In fact, these two statistics point to the same results: pedicle screwing in the thoracic spine may be problematic.
Although the literature highlights the advantages of computer-assisted techniques, we believe that the conventional technique is still a safe and feasible option for pedicle screw positioning. The main disadvantage of computer-based systems is their cost. Our results using the conventional technique are close to the rates reported for the image-guided techniques. The conventional technique is still a viable option for centers with limited resources.

\section{REFERENCES}

1. Amato V, Giannachi L, Irace C, Corona C: Accuracy of pedicle screw placement in the lumbosacral spine using conventional technique: Computed tomography postoperative assessment in 102 consecutive patients. J Neurosurg Spine 12:306-313, 2010

2. Amiot LP, Lang $\mathrm{K}$, Putzier M, Zippel H, Labelle H: Comparative results between conventional and computer-assisted pedicle screw installation in the thoracic, lumbar, and sacral spine. Spine (Phila Pa 1976) 25:606-614, 2000

3. Belmont PJ Jr, Klemme WR, Dhawan A, Polly DW Jr: In vivo accuracy of thoracic pedicle screws. Spine (Phila Pa 1976) 26:2340-2346, 2001

4. Gertzbein SD, Robbins SE: Accuracy of pedicular screw placement in vivo. Spine (Phila Pa 1976) 15:11-14, 1990

5. Guzey FK, Emel E, Seyithanoglu MH, Bas NS, Ozkan N, Sel B, Aycan A, Alatas I: Accuracy of pedicle screw placement for upper and middle thoracic pathologies without coronal plane spinal deformity using conventional methods. Journal of Spinal Disorders \& Techniques 19:436-441, 2006

6. Hart RA, Hansen BL, Shea M, Hsu F, Anderson GJ: Pedicle screw placement in the thoracic spine: A comparison of imageguided and manual techniques in cadavers. Spine (Phila Pa 1976) 30:E326-331, 2005

7. Hartl R, Theodore N, Dickman CA, Sonntag VKH: Technique of thoracic pedicle screw fixation for trauma. Operative Techniques in Neurosurgery 7:22-30, 2004

8. Kosmopoulos V, Schizas C: Pedicle screw placement accuracy: A meta-analysis. Spine (Phila Pa 1976) 32:E111-120, 2007

9. Kotil K, Bilge T: Accuracy of pedicle and mass screw placement in the spine without using fluoroscopy: A prospective clinical study. Spine Journal 8:591-596, 2008

10. Kuntz Ct, Maher PC, Levine NB, Kurokawa R: Prospective evaluation of thoracic pedicle screw placement using fluoroscopic imaging. J Spinal Disord Tech 17:206-214, 2004

11. Laine T, Lund T, Ylikoski M, Lohikoski J, Schlenzka D: Accuracy of pedicle screw insertion with and without computer assistance: A randomised controlled clinical study in 100 consecutive patients. Eur Spine J 9:235-240, 2000

12. Learch TJ, Massie JB, Pathria MN, Ahlgren BA, Garfin SR: Assessment of pedicle screw placement utilizing conventional radiography and computed tomography: A proposed systematic approach to improve accuracy of interpretation. Spine (Phila Pa 1976) 29:767-773, 2004 
13. Lieberman IH, Togawa D, Kayanja MM, Reinhardt MK, Friedlander A, Knoller N, Benzel EC: Bone-mounted miniature robotic guidance for pedicle screw and translaminar facet screw placement: Part I--Technical development and a test case result. Neurosurgery 59:641-650; discussion 641-650, 2006

14. Lonstein JE, Denis F, Perra JH, Pinto MR, Smith MD, Winter RB: Complications associated with pedicle screws. J Bone Joint Surg Am 81:1519-1528, 1999

15. Ludwig SC, Kowalski JM, Edwards CC, 2nd, Heller JG: Cervical pedicle screws: Comparative accuracy of two insertion techniques. Spine (Phila Pa 1976) 25:2675-2681, 2000

16. Merloz P, Tonetti J, Pittet $L$, Coulomb M, Lavallee S, Sautot P: Pedicle screw placement using image guided techniques. Clin Orthop Relat Res:39-48, 1998

17. Nottmeier EW, Seemer W, Young PM: Placement of thoracolumbar pedicle screws using three-dimensional image guidance: Experience in a large patient cohort. J Neurosurg Spine 10:33-39, 2009

18. O'Brien MF, Lenke LG, Mardjetko S, Lowe TG, Kong Y, Eck $\mathrm{K}$, Smith D: Pedicle morphology in thoracic adolescent idiopathic scoliosis: Is pedicle fixation an anatomically viable technique? Spine (Phila Pa 1976) 25:2285-2293, 2000

19. Rajasekaran S, Vidyadhara S, Ramesh P, Shetty AP: Randomized clinical study to compare the accuracy of navigated and non-navigated thoracic pedicle screws in deformity correction surgeries. Spine (Phila Pa 1976) 32:E56-64, 2007
20. Rivet DJ, Jeck D, Brennan J, Epstein A, Lauryssen C: Clinical outcomes and complications associated with pedicle screw fixation-augmented lumbar interbody fusion. J Neurosurg Spine 1:261-266, 2004

21. Sarlak AY, Buluc L, Sarisoy HT, Memisoglu K, Tosun B: Placement of pedicle screws in thoracic idiopathic scoliosis: A magnetic resonance imaging analysis of screw placement relative to structures at risk. European Spine Journal 17: 657-662, 2008

22. Schizas C, Theumann N, Kosmopoulos V: Inserting pedicle screws in the upper thoracic spine without the use of fluoroscopy or image guidance. Is it safe? Eur Spine J 16: 625-629, 2007

23. Tian NF, Xu HZ: Image-guided pedicle screw insertion accuracy: A meta-analysis. Int Orthop 33:895-903, 2009

24. Ugur HC, Attar A, Uz A, Tekdemir I, Egemen N, Genc Y: Thoracic pedicle: Surgical anatomic evaluation and relations. Journal of Spinal Disorders 14:39-45, 2001

25. Wiesner L, Kothe R, Ruther W: Anatomic evaluation of two different techniques for the percutaneous insertion of pedicle screws in the lumbar spine. Spine (Phila Pa 1976) 24: 1599-1603, 1999

26. Wiesner L, Kothe R, Schulitz KP, Ruther W: Clinical evaluation and computed tomography scan analysis of screw tracts after percutaneous insertion of pedicle screws in the lumbar spine. Spine (Phila Pa 1976) 25:615-621, 2000 